\title{
Assessment of use and quality of library services, accessibility and facilities by students at Cape Peninsula University of Technology
}

\author{
Deborah Becker ${ }^{1}$, Hillary Hartle ${ }^{2}$ and Gugu Mhlauli ${ }^{3}$ \\ beckerd@cput.ac.za ORCID: 0000-0001-9974-8622 \\ hartleh@cput.ac.za ORCID: orcid.org/0000-0003-3649-8405 \\ mhlaulig@cput.ac.za ORCID: orcid.org/0000-0003-3656-4740
}

\begin{abstract}
Received: 13 April 2017
Accepted: 19 June 2017

The purpose of this study was to investigate the use of library services and facilities by students at Cape Peninsula University of Technology and, in particular, gather feedback with regards to service satisfaction, accessibility and use of facilities. The investigation, carried out in March 2015, was based on a triangulation approach including surveys, informal interviews and an observation study. A total of 394 students responded to the survey. Their opinions supported information gathered from other surveys and available statistics. The results indicated that, although demand for some services such as circulation and reference transactions are decreasing, the number of visits to library facilities is increasing. While students prefer using online resources, they still choose face-to-face interaction with library staff as their first choice of contact, followed by email. Information literacy training, seen as essential by librarians, is rated as 'least important' by respondents. It was revealed that, although students show little interest in following the library on social media, they indicate a growing need for online tutorials and a growing use of library LibGuides. Furthermore, it is acknowledged that the services provided by staff are seen as important and students tend to use the library mainly for individual study, research, and group study. The study supported the fact that the changes made to library spaces and services are meeting the demands of library users, although there is still room for improvement.
\end{abstract}

Keywords: academic libraries, surveys, service satisfaction, library facilities, library services

\section{Introduction}

The academic library plays a pivotal role in supporting teaching, learning and research. In support of this role, the library needs to provide resources, facilities and services which will enable students to fulfil their academic potential. The library is further expected to support university plans for better student retention and reduction of dropout rates. In order to perform these activities, libraries constantly need to reassess their services to ensure they meet the needs of all stakeholders.

Over the past ten years, Cape Peninsula University of Technology (CPUT) Libraries has introduced or expanded on a number of library services provided to staff and students. While many of the new services introduced (such as online recording of statistics and electronic resource fairs), were due to changes in technology and developments within the library world, the library also enhanced existing services in areas such as information literacy, collaboration with faculties, and research spaces for postgraduate students. All these developments were underlined by perceived needs, whether they were to streamline activities of library staff or to improve the user experience. Engagement with staff and students as to their appreciation of library resources and their ability to use the resources provided by the library often formed the basis for service development and at the same time cemented a closer working relationship with faculties, research units and various administrative sections within the university.

While the majority of students at the university study towards diplomas and Bachelor of Technology (B.Tech) degrees, the university provides postgraduate degrees in an increasing number of selected disciplines. In most disciplines these are at master's or doctorate level; in the field of Education, in addition to the bachelor's degree (B.Ed), honours degrees are also conferred. Even with the emphasis on advanced degrees, the university supports students who need to bridge the gap between high school and university by offering Extended Curriculum Programmes (ECP) in identified subject areas (Cape Peninsula University of Technology 2017), enabling students to complete their first year of study over two years.

The challenge for CPUT Libraries is providing the correct level of support, services, spaces and materials for the vast range of students supported by the university, as well as staff who are being encouraged to engage actively in research activities.

1. Deborah Becker is Librarian: Quality Assurance and Library Research Support, Cape Peninsula University of Technology

2. Hillary Hartle is Marketing Librarian, Cape Peninsula University of Technology

3. Gugu Mhlauli is Assistant Librarian: Quality Assurance, Cape Peninsula University of Technology 


\section{Problem statement}

The exponential growth of information, the advances in technological tools for access and use of information has increasingly created many challenges for the traditional library service provision models - such as the localisation of physical items and their usage. Millennials and the Net Generation, raised with computer-based technologies, make up the majority of academic library users. These users have different approaches to accessing information than older generations have. Google and other open search platforms have become the main entry point for the search for and access to information by students in university libraries. In order to assess the level of satisfaction with library services, as well as identify areas for improvement and future development, it was determined that a survey be developed to cover all aspects of library activities.

CPUT Libraries had previously undertaken a LibQUAL+ survey and re-running the survey would enable the library to determine progress on issues previously marked as requiring improvement; however, it was decided that the LibQUAL+ questions were too general and would not assist with extracting the level of feedback currently required.

The key purpose of the study was twofold: firstly, to determine if and how students engage with the library as part of their studies and, secondly, to determine how well the library supports the academic activities of students. Feedback on these issues would enable the library to evaluate the value of its services and motivate for resources which could make the necessary adjustments to better support the needs of the students. A number of areas were identified for inclusion in the research. These could broadly be divided into four categories, namely,

- $\quad$ resources (including physical collections and online resources, most-used databases and e-book packages, finding resources and awareness of different types of resources);

- $\quad$ facilities (including space utilisation and activities done in the library);

- $\quad$ services provided by the library (including customer service, research assistance and access to resources) and training provided by staff; and

- $\quad$ marketing (including use of the library website, satisfaction with and importance of website content) and information about the library.

Only facilities and services are discussed in this study. The full survey may be seen in Appendix A. It was further determined that a survey was one dimensional and that a triangulated approach was needed in order to retrieve the required level of information. It was therefore decided that the survey would be supported by informal interviews with selected students and an observation survey at two of the campus libraries.

\section{Literature review}

Academic libraries are constantly evaluating the level of user satisfaction with library services, including both the services provided by specialist staff and general access to library facilities and materials (within the library and online). In support of this constant demand for feedback, a variety of tools has been developed to assist libraries to determine service quality. One of these tools is LibQUAL+, a web-based survey which contains twenty-two predetermined questions and focuses on service provision, information control and the library as place. Use of the survey allows libraries to benchmark themselves against other similar libraries. Such comparative data enables libraries to identify areas for improvement, best practice and resource allocation (Association of Research Libraries 2015).

\subsection{Service quality}

Another tool, SERVQual attempts to determine the quality of the services provided by libraries. The level of user expectation and satisfaction are determined based on ten dimensions and twenty-two questions. The gap between these two factors indicates the quality of the service. Based on SERVQual, a conceptual framework was developed by Hernon and Altman (Hernon and Calvert 1996) for use in academic libraries.

\subsection{Student behaviour}

The Ethnographic Research in Illinois Academic Libraries (ERIAL) Project (Asher, Duke \& Green 2010) resulted in the development of a toolkit to guide libraries in the use of ethnographic studies of student behaviour. The goal of the project was to understand how students conduct research and how the process is determined by the relationship between students, their lecturers and librarians (Asher and Miller 2011). Although time-intensive, this study advocates personal interviews with subjects and allows for a better understanding of their perceptions. A study done at the University of Rochester (Burns \& Harper 2007) covered various aspects of student behaviour including research, what students do and where they go, what they expect from libraries (for example, space, hours and website), how their needs have changed, as well as how to set up a student-centred library. The results were written up in eleven papers, each covering a different area of research.

\subsection{Library space}

In other studies, Suarez (2007) looked at what students do when they study in the library and how library space should be designed to accommodate current methods of library use; while Bennett (2005) indicated that we need to ask the right questions of students, concentrating on how they learn rather than on library operations when planning libraries and library space. He stated that libraries must develop spaces for both active learning and the social aspects of learning. Bedwell and Banks (2013) used an observation study to determine the flow of students through the library, the use of library spaces, and to point out areas where problems are experienced, for example, areas with bad lighting or noise. The common 
denominator in the above-mentioned studies is the engagement with students in the development of library spaces whether physical or virtual - so that spaces can be best suited to their needs. Knight (2013) indicated that, based on the needs of the curriculum, the most appropriate format of resources should be identified in collaboration with faculty and that marketing and training in the use of resources should be ongoing.

According to Gibbons and Foster (2007), society has evolved into a self-service community, influencing the expectations of the students and the services of the library. Academic libraries offer a range of facilities to students - ranging from seating spaces, study carrels, seminar rooms for collaborative learning spaces to computer labs; and often house academic support services such as writing centres and student counselling. Increasingly, libraries are redesigning their spaces to cater for the next generation of users (Lippincott 2005) who, although technologically-savvy and active participants in social media (mainly via cell phones), are comfortable in the traditional spaces provided by libraries, thereby bridging the two cultures. However, according to Microsoft (2003), the difference to previous generations is the increase in "non-traditional" students who are often older students studying part-time and balancing careers, families and studies. New, redesigned spaces catering for these diverse needs are attracting more numbers to libraries. In her research, Applegate (2009) indicated that, while study rooms (especially those for use by groups) are a favourite work area in the library, students still frequently use the study carrels which provide an acceptable option to students during busy periods when preferred study areas such as group study rooms or study cubicles are not available.

\subsection{Survey templates}

To assist academic libraries with developing surveys, various organisations have provided templates which can be used in studies either as guidelines or as they are. The Society of College, National and University Libraries (SCONUL) developed its first template in 1996 and has updated it twice since conception, the most recent update (with two variations) being in 2005. The survey concentrates on library services and includes questions covering demographics, library activities, rating of satisfaction and importance of services and facilities, as well as overall satisfaction with the service provided by the library (SCONUL 2017). The Library Research Service (2016) provides three templates. The short survey focuses on customer satisfaction while the medium survey includes library usage and the long survey is further extended to include demographics. Various academic libraries such as Massachusetts Institute of Technology (MIT) provide links to library surveys which can be viewed online.

\section{Methodology}

A triangulation approach, which combines both qualitative and quantitative data, was used for this study. Although the key focus of the study revolved around a survey methodology (based on the distribution of questionnaires), it was supported by informal interviews with students and an observation study.

A single questionnaire (see Appendix A), divided into six sections, each of which covered a specific topic, was developed. The first section required users to provide general information such as year of study, faculty and campus. Sections 2 and 3 covered online access and the library website. Section 4 looked at the library collection, while the final sections covered library services and facilities. A variety of question types were included in the survey. The most frequentlyused question types were multiple-choice questions which enabled respondents to select one (or at times more than one) answer and questions with rating scales which asked respondents either to rate the importance and/or the significance of certain statements. The Inqwise online survey tool was used to create and electronically distribute the survey to all students and staff members at CPUT. In addition, for the period of one week from 23 to 30 March 2015, links to the survey were posted on various platforms, including Blackboard (CPUT's Learning Management System) and the CPUT and Library websites as well as on Facebook and Twitter.

In a parallel process, librarians approached students at random, both inside and outside the library, and interviewed them using a short list of questions about their experiences with regards to the library's online services. The interviews were informal and were aimed at providing insight into choices made in the survey. An observation survey was undertaken at two of the campus libraries and was conducted by a library staff member at random times between 08h00 and $16 \mathrm{~h} 00-$ generally the busiest times in the library. Data was collected by recording the number of students within each section of the library on a diagram portraying the library layout. The purpose of the observation study was to compare student actions against criteria selected and are listed in Table 4.

Inqwise provided summaries of the answers to each survey question. Data from the observation study and interview process were analysed using various tools, including Atlas $\mathrm{Ti}$ (for qualitative data) and Microsoft Excel for quantitative data. The data collected during the survey period were supplemented by information already available to library staff, including the Library Information System, Aleph, and its reporting counterpart, the Aleph Reporting Center (ARC); the Library statistical database; CPUT Management Information Services data; Google Analytics; Library reports; and previous surveys. All these resources were used to evaluate the current status of student behaviour at CPUT Libraries. Although the survey was distributed to staff and students across all faculties and study levels, only responses by students have been included in the study. This decision was largely due to the small number of staff who responded to the survey.

\section{Findings}

In total, 394 responses to the online survey were received. Respondents were from all faculties and represented all years of study for undergraduate students, as well as postgraduate students. Second-year students represented $44 \%$ of the respondents, followed by fourth-year B.Tech and B.Ed students $(21 \%)$ and third-year students (20\%). Postgraduate students (honours, master's and doctorate) only made up $3 \%$ of respondents, while first-year students accounted for $6 \%$. 
As only four academic staff (2\%) responded to the survey, their responses have not been included in the analysis. Eight of the eleven campuses were represented in the survey. Although 394 is a very small percentage of the total number of students $(32,364)$ at the university, even fewer answered some of the questions. In some cases less than $10 \%$ of the respondents answered a question, making it very difficult to determine opinions based on campus or faculty. Most of these questions related to online access, the library website and comments about facilities and space usage. However, when survey responses were compared to statistical data collected by the library, they invariably supported the findings and trends of the collected data. The university library is often seen as the "heart of the university" (Olsen 2006), providing support for teaching, learning and research to all students and staff. With an increased emphasis on student retention, feedback on the levels of service provided is essential for future planning of library services, allocation of staff and identification of areas for improvement.

\subsection{Service satisfaction}

Along with statistical data available, qualitative input by library users enables the library to develop an overview of the service it provides. Library statistics collected internally for the period 2010-2014 and recorded by the Library Management System, Aleph, and the Library statistical database, show that the focus of library users has changed. In response, the library has adapted its services to suit the new demands.

Collected statistics indicate that usage of the print collection has been decreasing for the past four years: by $17 \%$ in 2013 and by a further $7 \%$ in 2014. After initial high increases, the number of full-text downloads from databases has stabilised; however, the use of e-books is still increasing with a 93\% increase in e-book page downloads since 2011. The library's response has been to streamline the printed collection, thereby creating more space for group and individual study areas. More computers have been secured and provision has been made for laptop usage.

Recently, researchers in the field of Library and Information Science have focused on the meeting of expectations of library users and considering users' perspectives in order to determine the quality of services provided (Kiran 2010). Kiran (2010) also indicated that if users continually experience satisfaction with the service provided, they perceive the service to be of high quality. In the survey (Appendix A), questions relating to service satisfaction address two main areas: Customer service (C) and Research support (R). Respondents were asked to indicate their level of satisfaction with the service as well as rate the importance of each statement in Table 1.

\section{Table 1 Statements for which respondents were asked to rate their level of satisfaction}

\begin{tabular}{ll}
\hline C1 & I am treated with respect \\
C2 & I feel comfortable asking staff questions \\
C3 & Staff are approachable \\
C4 & Staff are friendly \\
C5 & Staff are knowledgeable \\
C6 & Staff are professional \\
C7 & Staff do what they say they will do \\
C8 & Staff provide appropriate answers \\
C9 & Staff provide quality service \\
C10 & Staff respond within an acceptable time \\
C11 & Staff take interest in me and my needs \\
& \\
R1 & Assistance from staff at the information desk \\
R2 & Assistance from faculty librarians \\
R3 & Assistance from library staff using email or SMS \\
R4 & Faculty LibGuides \\
R5 & Information literacy training \\
R6 & Mendeley workshops \\
R7 & Postgraduate support \\
\hline
\end{tabular}

The scatter graph (Figure 1) presents an overview of the responses received. The letters indicate the type of service, and the number represents the statement offered. All the customer service statements were registered as having a high level of importance and received a very high satisfaction rating. After the results of the LIBQUAL+ survey undertaken in 2008 revealed that the service issues did not meet the desired standards (although perceived as greater than minimum), the library implemented an action plan to address the issues. Actions taken included: customer services training for all relevant staff, reorganising of the information services staff to provide more support for faculty librarians, and changing spaces to provide librarians with office space while assisted by staff seated in open spaces on the floor. The current perception implies a positive response to the actions taken. 


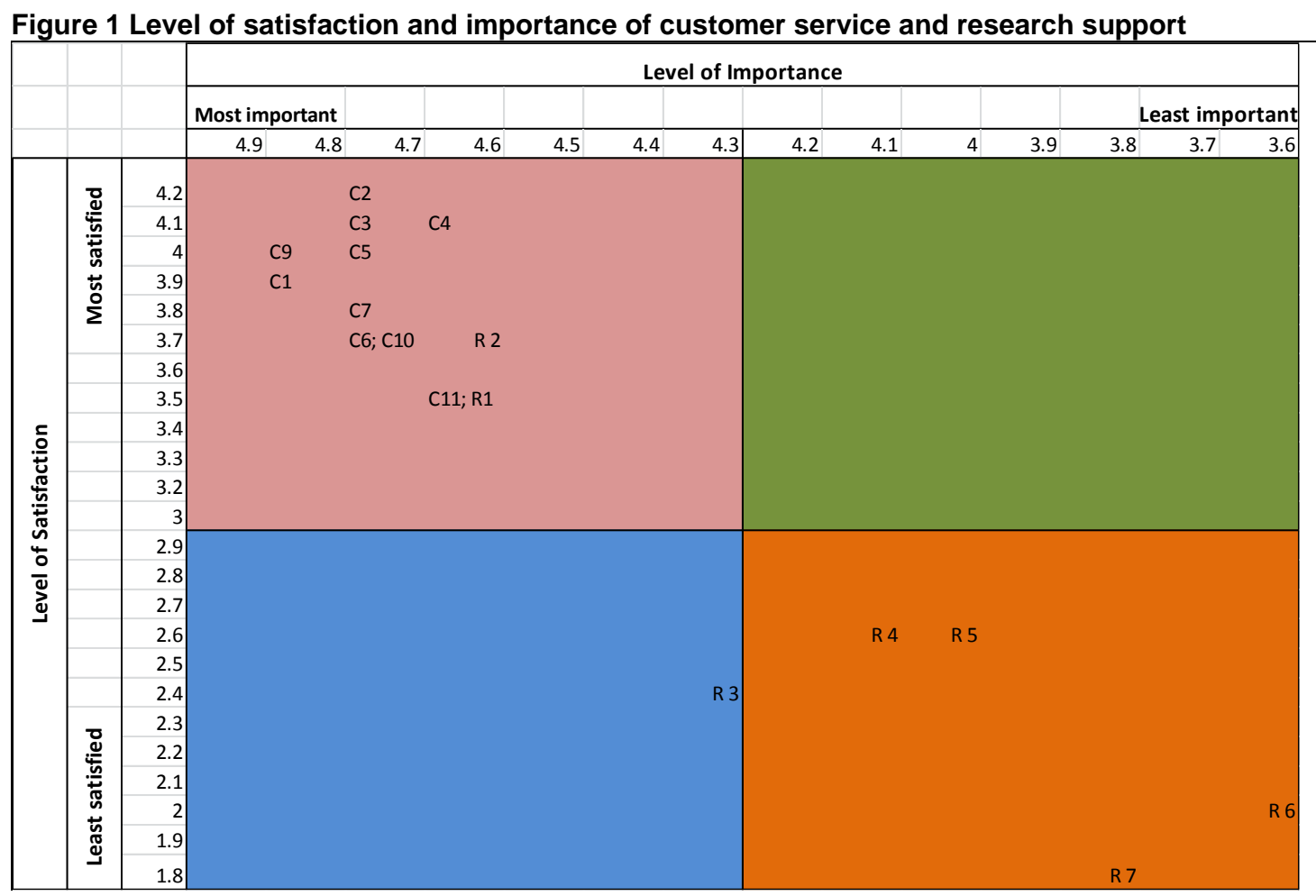

Although the numbers of loan and reference transactions have been declining over the past three years, respondents indicated that they were satisfied with all the important service issues. The area of least satisfaction was with research support. This area was also rated least important; however, this is an area of lesser importance to undergraduate students who formed the bulk of the respondents $(91 \%)$ to the survey. The questions relating to Mendeley workshops and postgraduate support were only answered by twenty-nine students of which six were postgraduate. Of concern, and an area to be further investigated, is the low level of importance (and satisfaction) given to information literacy training. One possible explanation for this response may be that, while most information literacy training is provided for first-year students, only $6 \%$ of respondents represented this group.

The three statements which respondents rated as most important (and with the highest level of satisfaction) related to the quality of service provided by staff, the respect shown to library users by staff, and the freedom respondents felt in asking staff questions. The statement rated least important was about the Mendeley workshops and the statement with the lowest satisfaction level related to postgraduate support. Further analysis indicated that, although $80 \%$ of the postgraduate students who answered the question felt that the postgraduate research support services were important, only 30\% indicated a rating of 'satisfied' or 'very satisfied'. According to the data recorded on the statistical database for $2014,4.1 \%$ of the total student population at CPUT were postgraduate students. Although they accounted for only $1.3 \%$ of all library visits, $10.8 \%$ of all queries were directed to staff in the postgraduate student area. With the ever-increasing focus on research at the university, the figures are of concern. In general, the comments received which related to service questions were very positive. The main areas of concern identified were library security and the checking of bags upon entry to the library which was seen to be disrespectful. The questionnaire asked respondents to rate how often they used various services. The services listed and corresponding responses can be seen in Table 2.

Google, Yahoo or other non-library information were used daily by $57 \%$ of respondents, while $21 \%$ indicated they used online resources (databases or e-books) provided by the library on a daily basis. Although $25 \%$ of respondents indicated they never used online resources provided by the library, statistics show a 26\% increase in e-book usage between 2013 and 2014. This statistic supports Chandrasekar and Murugathas (2012), who stated that digital access has influenced how students access materials and thereby services provided by the library. The high usage of Google and Yahoo support the observation by Rieger (2009) that up to $89 \%$ of students and faculty members use search engines as a starting point for information searches, with $68 \%$ selecting Google, which may be indicative of the interface preferences of respondents and focuses the attention on how electronic content is packaged and accessed. Over $80 \%$ of respondents indicated that they never used services such as inter-branch and inter-library loans or the drop box for returning items. This percentage is supported by statistics recorded in library documentation that show that inter-library loan requests for items requested by CPUT have dropped by $198 \%$ over the past five years, with the number of e-copies exceeding the number of printed articles received.

While $46 \%$ of students indicated they 'seldom' required assistance from staff, $7 \%$ said they 'never' required assistance and $7 \%$ indicated they required assistance from staff daily. According to the library's statistical database, there has been a $28 \%$ decrease in the number of reference queries handled by librarians since 2010 . However, $23 \%$ of students indicated that they would appreciate online assistance from librarians and $23 \%$ indicated they would like access to online tutorials 
explaining library materials and services. These requests by students seem to support the need for a more remote support structure and are related to the ease with which students have access to online data, either via cell phones or other sources and the students' willingness to use technology in their learning behaviour (Ajiboye \& Tella 2007). The items with the highest levels of weekly access were computers, scanners and printers in the library $(32 \%)$ followed by assistance from library staff $(25 \%)$; while the highest levels of monthly access was the use of printed books or journals (32\%), followed by the use of the library catalogue to find library materials (29\%).

Table 2 Frequency of use of services

\begin{tabular}{lccccc}
\hline & Never & Seldom & Monthly & Weekly & Daily \\
\hline Assistance from library staff & $7 \%$ & $46 \%$ & $14 \%$ & $25 \%$ & $7 \%$ \\
Computers, scanners, printers in the library & $14 \%$ & $29 \%$ & $11 \%$ & $32 \%$ & $14 \%$ \\
Digital Knowledge for theses & $54 \%$ & $25 \%$ & $7 \%$ & $11 \%$ & $4 \%$ \\
Drop box for returning books when the library is closed & $82 \%$ & $11 \%$ & $4 \%$ & $0 \%$ & $4 \%$ \\
E-journal list to identify online library journals & $32 \%$ & $43 \%$ & $14 \%$ & $4 \%$ & $7 \%$ \\
Online renewal of items & $64 \%$ & $21 \%$ & $4 \%$ & $7 \%$ & $4 \%$ \\
Google, Yahoo or other non-library information platforms & $18 \%$ & $11 \%$ & $4 \%$ & $11 \%$ & $57 \%$ \\
Inter-branch loans & $82 \%$ & $14 \%$ & $0 \%$ & $0 \%$ & $4 \%$ \\
Inter-Library loans & $82 \%$ & $14 \%$ & $0 \%$ & $0 \%$ & $4 \%$ \\
Library spaces for individual study or work & $18 \%$ & $36 \%$ & $18 \%$ & $14 \%$ & $14 \%$ \\
Library spaces for group work & $32 \%$ & $32 \%$ & $11 \%$ & $21 \%$ & $4 \%$ \\
Library website for accessing research guides & $11 \%$ & $46 \%$ & $14 \%$ & $21 \%$ & $7 \%$ \\
Library website for finding information about the library & $29 \%$ & $32 \%$ & $18 \%$ & $11 \%$ & $11 \%$ \\
\hline LibGuides & $48 \%$ & $22 \%$ & $19 \%$ & $4 \%$ & $7 \%$ \\
Links on library pages & $32 \%$ & $43 \%$ & $18 \%$ & $0 \%$ & $7 \%$ \\
Off-campus access & $36 \%$ & $32 \%$ & $7 \%$ & $14 \%$ & $11 \%$ \\
Online resources (books or journals) & $25 \%$ & $29 \%$ & $11 \%$ & $14 \%$ & $21 \%$ \\
Online information literacy course & $38 \%$ & $38 \%$ & $12 \%$ & $8 \%$ & $4 \%$ \\
Printed books or journals & $18 \%$ & $29 \%$ & $32 \%$ & $14 \%$ & $7 \%$ \\
The library catalogue to find library items & $11 \%$ & $39 \%$ & $29 \%$ & $11 \%$ & $11 \%$ \\
\hline
\end{tabular}

Responses seem to indicate that, of the listed services, students are least interested in following the library on social media ( $97 \%$ never or seldom access the library Facebook page) or using the sources created by librarians with LibGuides $(70 \%)$ and the online information literacy course (76\%) seldom or never being used. However, a recent report on LibGuides usage indicated that the usage of LibGuides in 2015 (50,657 views) had doubled compared to 2014 usage (25,891 views). The increase in the use of LibGuides can be attributed to their use in accessing relevant resources during information literacy training; thereby alerting students to LibGuides as the main source for subject-related information and resources.

\subsection{Dealing with library staff}

As shown in Table 3, in response to the survey question, "Please indicate your preference for dealing with library staff", the highest response by students for their first choice was 'personal contact' followed by email. Email was the most selected option for second and third choices. These responses support behavioural changes in communication due to the influence of and familiarity with expanding technology. Drago (2015) reported that $46 \%$ of students interviewed at Elon University indicated they more frequently used technology to communicate than direct face-to-face interaction, though $26 \%$ disagreed. Most students currently have smart phones which give them the option of easily communicating by email or text message should they not be able to have a face-to-face conversation with a staff member while in the library. Feedback from respondents indicates that the telephone is not a serious option for most respondents.

Table 3 Responses on method of correspondence with staff

\begin{tabular}{|c|c|c|c|c|c|c|c|c|c|}
\hline & Email & $\begin{array}{c}\text { From } \\
\text { Blackboard }\end{array}$ & $\begin{array}{c}\text { From } \\
\text { faculty } \\
\text { Libguides }\end{array}$ & $\begin{array}{c}\text { From } \\
\text { Library } \\
\text { webpage }\end{array}$ & $\begin{array}{c}\text { Library } \\
\text { Facebook } \\
\text { page }\end{array}$ & $\begin{array}{c}\text { Personal } \\
\text { contact }\end{array}$ & Telephone & $\begin{array}{l}\text { Texting } \\
\text { (SMS) }\end{array}$ & Other \\
\hline First choice & $29 \%$ & $14 \%$ & $4 \%$ & $0 \%$ & $0 \%$ & $46 \%$ & $4 \%$ & $0 \%$ & $4 \%$ \\
\hline Second choice & $32 \%$ & $18 \%$ & $4 \%$ & $7 \%$ & $4 \%$ & $4 \%$ & $11 \%$ & $18 \%$ & $4 \%$ \\
\hline Third choice & $25 \%$ & $7 \%$ & $7 \%$ & $18 \%$ & $4 \%$ & $14 \%$ & $11 \%$ & $7 \%$ & $7 \%$ \\
\hline
\end{tabular}




\subsection{Accessibility and use of facilities}

Applegate (2009) states:

It is a mistake to think of the library only as a place where services such as reference, instruction, and computer use are provided. The library is a campus space, one uniquely suited to meet important student needs for space as well as services and resources.

Although it is widely recognised that the internet and digital collections are changing the way students access library materials (Chandrasekar \& Murugathas 2012), students at CPUT still require library space for study and research. The responses by students to the question, "Where do you feel most comfortable accessing library materials?" indicates that $47 \%$ find CPUT Libraries the most comfortable space, followed by home (23\%) and the CPUT E-Learning Centre (10\%). Only $3 \%$ of respondents were comfortable accessing library materials from their dormitories. This finding differs from the findings of Thaler and Pittman (2015) who found that students in dormitories prefer studying alone in their dormitories rather than in the library. When asked what activities were undertaken most often in the library, the highest number of responses by students related to the use of library spaces and the lowest number related to the use of collections and requesting assistance from a librarian. These results may be seen in Table 4.

\begin{tabular}{lc} 
Table 4 Use of facilities & \\
\hline Individual study & $16 \%$ \\
Research & $16 \%$ \\
Group study & $14 \%$ \\
Use computers, printers, scanners & $14 \%$ \\
Use photocopiers & $10 \%$ \\
Take out library items & $8 \%$ \\
Use the print collection & $7 \%$ \\
Request assistance from a librarian & $6 \%$ \\
Use the online collection & $6 \%$ \\
\hline
\end{tabular}

As recorded in a survey of students at Milner Library at Illinois State University (Hunter \& Ward 2011), many students come to the library to study as they need either a quiet space or a space with fewer distractions. At CPUT, $16 \%$ of respondents indicated that they use the library most frequently for individual study or research, followed by $14 \%$ who indicated they use the library for its computers, printers or scanners, or for group study. Only $6 \%$ of respondents stated that they use the library to request assistance from a librarian or access the online collection and $7 \%$ came to the library to use the print collection.

Four of the larger CPUT branches are undergoing some changes to the allocation of space, creating more group study areas and open space for interactivity and discussion. Extra work space for students has been created by streamlining the print collection, moving duplicate and lesser-used items into a storage facility. More seats and laptop access areas are being made available. Library users have expressed their support for these efforts by the relatively high ratings provided. Library statistics over the past few years show that, although transactions and interactions with staff are decreasing, the number of visitors to the library continues to increase. Over $80 \%$ of respondents were satisfied with the following statements about the library:

- The library is comfortable and inviting

- Convenient service hours

- The library inspires study and learning.

A higher number of students (72\%) were satisfied with the facilities provided for group work while $62 \%$ of students were satisfied with the computer facilities provided, despite the long queues often experienced by students waiting to use the computer facilities.

\section{Conclusion}

The results of the survey reinforce the trends seen in the library statistics collected monthly and annually and support the actions taken by the library to develop user spaces, improve computer facilities and promote electronic resources. Overall, library users (students and staff) have indicated that they appreciate the value the library adds to their academic activities. Although library users are inclined towards using electronic materials, as indicated by many responses provided, they have added comments about problems with computer and wireless access and provide insight into the frustrations experienced when using these resources. These comments reiterate those made in earlier surveys, but in many cases the solution does not lie within the scope of the library. The library has actively promoted its services via annual marketing campaigns and ongoing information literacy training. The survey has indicated very high awareness of these services; however, the survey 
also showed that many respondents did not know how to access resources efficiently. Face-to-face interaction with staff is still highly rated, even though email is becoming more popular. However, such interaction is declining with many respondents (46\%) indicating that they seldom request assistance from staff. The main reason for students using the library is to use the space provided. Respondents indicated that they enjoy the library space and find it the most comfortable way to access resources. The on-going demand for seminar rooms and study cubicles also emphasises the need for the library to provide a variety of different environments to suit the individual needs of its users. Irrespective of the online or physical resources and services provided by the library, library space appears to be highly valued.

\section{References}

Ajiboye, J.O. and Tella, A. 2007. University undergraduate students' information seeking behaviour: implications for quality in higher education in Africa. The Turkish Online Journal of Educational Technology - TOJET, 6 (1): article 4: 40-52.

Applegate, R. 2009. The library is for studying: student preferences for study space. The Journal of Academic Librarianship, 35(4): 341-346.

Asher, A. and Miller, S. 2011. So you want to do anthropology in your library? Or a practical guide to ethnographic research in academic libraries. [Online]. http://www.erialproject.org/wp-content/uploads/2011/03/Toolkit-3.22.11.pdf (14 January 2016).

Asher, A., Duke, L. and Green, D. 2010. The ERIAL Project: Ethnographic research in Illinois Academic Libraries. The Academic Commons for the liberal education community. [Online]. http://www.academiccommons.org/2014/09/09/the-erial-project-ethnographic-research-in-illinois-academic-libraries/ (3 February 2016).

Association of Research Libraries (ARL). 2008. LibQUAL+ 2008 survey: Cape Peninsula University of Technology Libraries - English \& Cape Peninsula University of Technology Libraries - Afrikaans. Washington: ARL.

Association of Research Libraries (ARL). 2015. Statistics and Assessment Programme: LibQUAL. [Online]. https://www.libqual.org/about/about_lq/general_info (11 January 2016).

Bedwell, L. and Banks, C. 2013. Seeing through the eyes of students: participant observation in an academic library. Partnership: The Canadian Journal of Library and Information Practice and Research, 8(1). [Online]. https://journal.lib.uoguelph.ca/index.php/perj/article/view/2502/2905\#.U1n896Jg_KE (11 January 2016).

Bennett, S. 2005. Righting the balance. In: Library as place: rethinking roles, rethinking space. CLIR report. [Online]. http://www.clir.org/pubs/reports/pub129/bennett.html (11 January 2016).

Burns, V. and Harper, K. 2007. Asking students about their research. In Studying students: the undergraduate research project at the University of Rochester. N.F. Foster and S. Gibbons, Eds. Chicago: ACRL.7-15.

Cape Peninsula University of Technology. 2017. Extended Curriculum Programme. [Online]. http://www.cput.ac.za/academic/faculties/appliedsciences/departments/biodiversity/qualifications/ecp (9 June 2017).

Chandrasekar, K. and Murugathas, K. 2012. An assessment of user satisfaction on library services: a case study of undergraduate biology students at the University of Jaffna. Journal of the University Librarians Association of Sri Lanka, 16(1): 34-45. [Online].

https://scholar.google.com/citations?view_op=view_citation\&hl=en\&user=vB9OSIUAAAAJ\&citation_for_view=vB9OSI UAAAAJ:U5HHmVD_uO8C (22 March 2016).

Drago, E. 2015. The effect of technology on face-to-face communication. The Elon Journal of Undergraduate Research in Communications, 6(1): 13-19. [Online] . https://www.elon.edu/docs/eweb/academics/communications/research/vol6no1/02DragoEJSpring15.pdf (22 March 2016).

Gibbons, S. and Foster, N.F. 2007. Library design and ethnography. In Studying students: the undergraduate research project at the University of Rochester. N.F. Foster and S. Gibbons, Eds. Chicago: ACRL. 20-29.

Hernon, P. and Calvert, P.J. 1996. Methods for measuring service quality in University Libraries in New Zealand. The Journal of Academic Librarianship, 22(5): 387-391.

Hunter, G. and Ward, D. 2011. Students research the library: using student-led ethnographic research to examine the changing role of campus libraries. C\&RL News, 72(5): 264-268. [Online]. http://crln.acrl.org/content/72/5/264.full (3 February 2016).

Kiran, K. 2010. Service quality and customer satisfaction in academic libraries: perspectives from a Malaysian university, Library Review, 59(4): 261-273. [Online]. DOI:10.1108/00242531011038578.

Knight, N. 2013. Enhancing access to library resources at Northern Caribbean University through an e-library initiative. [Online]. The Electronic Library, 31(6): 753-769. DOI:10.1108/EL-01-2012-0001.

Library Research Service. 2016. Library user survey templates \& how-tos [Online]. https://www.Irs.org/library-usersurveys-on-the-web/ (20 June 2016).

Lippincott, J.K. 2005. Net Generation students and libraries. EDUCAUSE review. March/April. 56-66. [Online]. https://net.educause.edu/ir/library/pdf/erm0523.pdf (3 February 2016).

Microsoft. 2003. Higher Education Leaders Symposium: the next-generation student. June 17-18, 2003. Redmond, Washington. [Online]. https://net.educause.edu/ir/library/pdf/NLI0425a.pdf (13 January 2016).

Olsen, R.J. 2006. The heart of the university. BYU Magazine. Summer Issue. [Online]. https://magazine.byu.edu/article/the-heart-of-the-university/ (23 March 2016).

Rieger, O.Y. 2009. Search engine use behaviour of students and faculty: user perceptions and implications for future research. First Monday. 14(12). [Online]. http://firstmonday.org/article/view/2716/2385 (3 February 2016). 
Society of College, National and University Libraries. 2017. SCONUL Satisfaction Survey - Guidance Notes. [Online]. http://www.sconul.ac.uk/page/sconul-statisfaction-survey-guidance-notes (30 August 2016).

Suarez, D. 2007. What students do when they study in the library: using ethnographic methods to observe student behavior. Electronic Journal of Academic and Special Librarianship, 8 (3): (Winter 2007). [Online]. http://southernlibrarianship.icaap.org/content/v08n03/suarez_d01.html (3 February 2016).

Thaler, M. and Pittman, T. 2015. A student view of academic libraries. Dialogue, 27: 9-10. [Online]. http://www.gensler.com/design-thinking/publications/dialogue/27/a-student-view-of-academic-libraries?o=31 (23 June 2016). 


\section{Appendix A}

\section{Studying students and their library use at Cape Peninsula University of Technology (CPUT) Libraries}

Please answer all the following questions as accurately as possible.

\section{Year of study (select the most appropriate)}

\begin{tabular}{|l|l|l|l|l|l|l|l|l|}
\hline $1^{\text {st }}$ year & $2^{\text {nd }}$ year & $3^{\text {rd }}$ year & $\begin{array}{l}4^{\text {th }} \text { year } \\
(\text { Btech/B.Ed })\end{array}$ & Honours & Master's & Doctorate & Academic Staff & Non-academic staff \\
\hline
\end{tabular}

\section{Faculty}

\begin{tabular}{|l|l|l|l|l|}
\hline Applied Science & $\begin{array}{l}\text { Business \& Management } \\
\text { Science }\end{array}$ & Education & Engineering & Health \& Wellness \\
\hline
\end{tabular}

\section{Campus}

\begin{tabular}{|l|l|l|l|l|l|l|l|l|l|l|l}
\hline Athlone & Bellville & $\begin{array}{l}\text { Cape } \\
\text { Town }\end{array}$ & George & $\begin{array}{l}\text { Granger } \\
\text { Bay }\end{array}$ & $\begin{array}{l}\text { Groote } \\
\text { Schuur }\end{array}$ & MediaCity & Mowbray & Tygerberg & Wellington & Worcester \\
\hline
\end{tabular}

\section{Part 1: Services and Facilities}

\section{General}

1. Do you agree with the following statements?

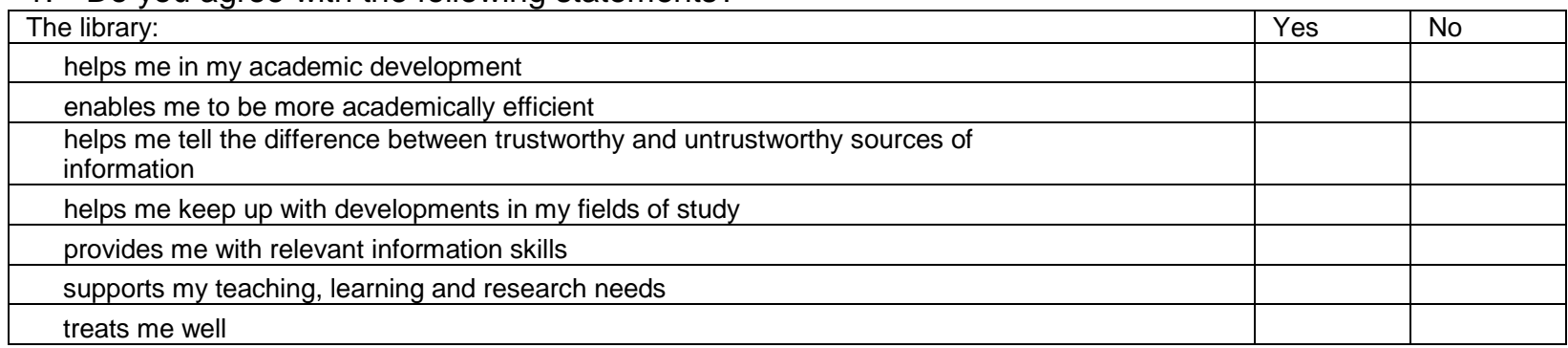

Do you have any comments you would like to add?

\section{Part 2: Online access}

1. From where do you most often access electronic resources provided by the library?

\begin{tabular}{|l|l|}
\hline My dormitory & \\
\hline My office & \\
\hline Elsewhere on campus & \\
\hline My campus library & \\
\hline Other (Please specify) & \\
\hline
\end{tabular}

2. Which of the following online services would you like the library to provide? You can select more than one. Chat and email features Online assistance from your librarians

RSS feeds for library news

RSS feeds for new books

The ability to customise the homepage with your favourite resources

Video tutorials explaining library materials and services

3. What e-book packages do you use most often? (Select up to three and list them in order of preference)

4. What databases do you use most often? (Input up to three and list then in order of preference)

5. What type of device do you use?

\begin{tabular}{|l|l|}
\hline Android phone & \\
\hline Blackberry & \\
\hline e-book reader (e.g. Kindle, Nook) & \\
\hline iPad & \\
\hline iPhone & \\
\hline iPod touch & \\
\hline Tablet & \\
\hline Other & \\
\hline
\end{tabular}


6. What are the main reasons for visiting the library website?

\section{Access databases}

Access e-books

Access to faculty LibGuides

General interest

Link to library Facebook page

Look for contact details

Look for library hours/branch information

New book lists

Online forms

Online information literacy training course

Professional interest

Search the library catalogue

7. Which of the following activities do you or would you like to use on your cell phone or tablet?

\begin{tabular}{|l|l|l|l|}
\hline \multicolumn{2}{|l|}{ Currently do } & Would Like to & Not interested \\
\hline Access library guides & & & \\
\hline Access library Facebook page & & & \\
\hline Listen to training sessions or podcasts & & & \\
\hline Read academic papers or journals & & & \\
\hline Read e-books & & & \\
\hline Renew library books & & & \\
\hline Request library items & & & \\
\hline Search for items in the library & & & \\
\hline Scan Library QR codes & & & \\
\hline Other & & & \\
\hline
\end{tabular}

8. From where do you feel most comfortable and access library materials the most?

\begin{tabular}{|l|l|}
\hline Another library & \\
\hline CPUT e-learning centre & \\
\hline CPUT IT centre & \\
\hline CPUT labs & \\
\hline Home & \\
\hline My CPUT library & \\
\hline My office & \\
\hline Residence & \\
\hline Work & \\
\hline
\end{tabular}

9. Do you prefer print or electronic access for the following?

\begin{tabular}{|l|l|l|}
\hline & Print & Electronic \\
\hline Fiction & & \\
\hline Journals & & \\
\hline Reference books & & \\
\hline Scholarly books & & \\
\hline Textbooks & & \\
\hline Theses and dissertations & & \\
\hline
\end{tabular}

\section{Part 3: The Library website}

1. Please indicate your satisfaction and the importance of the library website with regard to each of the comments below:

\begin{tabular}{|c|c|c|c|c|c|c|c|c|c|c|}
\hline & \multicolumn{5}{|c|}{ How satisfied are you? } & \multicolumn{5}{|c|}{ How important is it to you? } \\
\hline The library website ... & $\begin{array}{l}\text { Very } \\
\text { dis- } \\
\text { satisfied }\end{array}$ & $\begin{array}{l}\text { Dis- } \\
\text { satisfied }\end{array}$ & $\begin{array}{l}\text { Some- } \\
\text { what } \\
\text { satisfied }\end{array}$ & $\begin{array}{l}\text { Sat- } \\
\text { isfied }\end{array}$ & $\begin{array}{l}\text { Don't } \\
\text { know }\end{array}$ & $\begin{array}{l}\text { Not } \\
\text { important }\end{array}$ & $\begin{array}{l}\text { Somewhat } \\
\text { important }\end{array}$ & $\begin{array}{l}\text { Very } \\
\text { important }\end{array}$ & Essential & $\begin{array}{l}\text { No } \\
\text { opinion }\end{array}$ \\
\hline $\begin{array}{l}\text { has accurate and up-to-date } \\
\text { content }\end{array}$ & & & & & & & & & & \\
\hline has the resources I need & & & & & & & & & & \\
\hline is a good marketing tool & & & & & & & & & & \\
\hline is easy to navigate & & & & & & & & & & \\
\hline is useful & & & & & & & & & & \\
\hline provides the information I need & & & & & & & & & & \\
\hline $\begin{array}{l}\text { uses language which is easy to } \\
\text { understand }\end{array}$ & & & & & & & & & & \\
\hline
\end{tabular}


2. When using the website do you usually find ...

More than you expect to find

Some things you expect to find

Exactly what you expect to find

A few things you expect to find

Nothing you expect to find

\section{Part 4: The library collection}

1. Indicate your awareness and the importance of each of the following collections

\begin{tabular}{|c|c|c|c|c|c|c|c|c|c|}
\hline \multirow[b]{2}{*}{ Collection } & \multicolumn{2}{|c|}{$\begin{array}{l}\text { Are you aware of the } \\
\text { following } \\
\text { collections? }\end{array}$} & \multicolumn{2}{|c|}{$\begin{array}{l}\text { Do you use the } \\
\text { collections? }\end{array}$} & \multicolumn{5}{|c|}{ How important? } \\
\hline & Yes & No & Yes & No & $\begin{array}{l}\text { Not } \\
\text { important }\end{array}$ & $\begin{array}{l}\text { Somewhat } \\
\text { important }\end{array}$ & $\begin{array}{l}\text { Very } \\
\text { important }\end{array}$ & Essential & $\begin{array}{l}\text { No } \\
\text { opinion }\end{array}$ \\
\hline \multicolumn{10}{|c|}{ Audio-visual material } \\
\hline \multicolumn{10}{|c|}{ Charts } \\
\hline \multicolumn{10}{|c|}{ Institutional repository (DK) } \\
\hline \multicolumn{10}{|c|}{ Maps } \\
\hline \multicolumn{10}{|l|}{$\begin{array}{l}\text { Online books } \\
\text { Online journals }\end{array}$} \\
\hline \multicolumn{10}{|c|}{ Online textbooks } \\
\hline \multicolumn{10}{|l|}{ Popular fiction } \\
\hline \multicolumn{10}{|l|}{ Printed books } \\
\hline \multicolumn{10}{|c|}{ Printed journals } \\
\hline \multicolumn{10}{|c|}{ Short loan collection } \\
\hline \multicolumn{10}{|c|}{ Reference books } \\
\hline
\end{tabular}

2. When trying to find resources do you:

\begin{tabular}{|l|l|}
\hline Ask a library staff member & \\
\hline Browse the shelves & \\
\hline Search online & \\
\hline Search the catalogue & \\
\hline Other & \\
\hline All of the above & \\
\hline
\end{tabular}

3. Are you aware of the following tools for finding library information and how important are they to you?

\begin{tabular}{|c|c|c|c|c|}
\hline \multirow[t]{2}{*}{ Finding library material } & \multicolumn{2}{|c|}{ Awareness } & \multicolumn{2}{|c|}{\begin{tabular}{|l|l|}
\multicolumn{2}{|l}{} \\
Not
\end{tabular}} \\
\hline & Yes & No & $\begin{array}{l}\text { Not } \\
\text { important }\end{array}$ & $\begin{array}{l}\text { Some } \\
\text { import }\end{array}$ \\
\hline \multicolumn{5}{|l|}{ A-Z journal list } \\
\hline \multicolumn{5}{|l|}{ Database list } \\
\hline \multicolumn{5}{|l|}{ Faculty LibGuides } \\
\hline \multicolumn{5}{|l|}{ Google Scholar } \\
\hline \multicolumn{5}{|l|}{ Inter Branch loan } \\
\hline \multicolumn{5}{|l|}{ Inter Library loan } \\
\hline \multicolumn{5}{|l|}{ Library catalogue } \\
\hline \multicolumn{5}{|l|}{ Library website } \\
\hline \multicolumn{5}{|l|}{ Off-campus access } \\
\hline \multicolumn{5}{|l|}{ Online help facilities } \\
\hline \multicolumn{5}{|c|}{ 4. If the library has a print copy, but not an electronic copy of a } \\
\hline \multicolumn{5}{|c|}{\begin{tabular}{|l|l|} 
Borrow the print copy & \\
\end{tabular}} \\
\hline \multicolumn{5}{|c|}{ Find another suitable electronic title } \\
\hline \multicolumn{5}{|c|}{ Photocopy the print copy } \\
\hline \multicolumn{5}{|c|}{ Scan the print copy and print } \\
\hline Other & & & & \\
\hline
\end{tabular}

5. If the library has an electronic copy, but not a print copy of an item you need what do you do?

Print the electronic copy

Find another suitable print title

Request a print copy via Inter-library loans

Use the electronic copy

Other 
6. When trying to find electronic journals where do you start your research?

\begin{tabular}{|l|l|}
\hline Author's website & \\
\hline Google & \\
\hline Google scholar & \\
\hline Library catalogue & \\
\hline Library database list & \\
\hline Other search engines (e.g. Yahoo) & \\
\hline Publishers website & \\
\hline Worldcat & \\
\hline Other & \\
\hline
\end{tabular}

\section{When trying to find electronic books where do you start your research?}

\begin{tabular}{|l|l|}
\hline Author's website & \\
\hline Commercial e-book provider (e.g. Amazon) & \\
\hline Google & \\
\hline Google books & \\
\hline Google scholar & \\
\hline Library catalogue & \\
\hline Library e-book list & \\
\hline Other search engines (e.g. Yahoo) & \\
\hline Publisher's website & \\
\hline Worldcat & \\
\hline
\end{tabular}

\section{Part 5: Services}

1. Customer service - please indicate your level of satisfaction and importance for each of the following statements

\begin{tabular}{|l|l|l|l|l|l|l|l|l|l|}
\hline Customer service & \multicolumn{3}{|c|}{ How satisfied are you? } & \multicolumn{3}{c|}{ How important is it to you? } \\
\hline & $\begin{array}{l}\text { Very dis- } \\
\text { satisfied }\end{array}$ & $\begin{array}{l}\text { Dis- } \\
\text { satisfied }\end{array}$ & $\begin{array}{l}\text { Some- } \\
\text { what } \\
\text { satisfied }\end{array}$ & $\begin{array}{l}\text { Sat- } \\
\text { isfied }\end{array}$ & $\begin{array}{l}\text { Don't } \\
\text { know }\end{array}$ & $\begin{array}{l}\text { Not } \\
\text { importa } \\
\text { nt }\end{array}$ & $\begin{array}{l}\text { Somewhat } \\
\text { important }\end{array}$ & $\begin{array}{l}\text { Very } \\
\text { important }\end{array}$ & Essential \\
opinion \\
I am treated with respect & & & & & & & & & \\
\hline $\begin{array}{l}\text { I feel comfortable asking staff } \\
\text { questions }\end{array}$ & & & & & & & & & \\
\hline Staff are approachable & & & & & & & & & \\
\hline Staff are friendly & & & & & & & & & \\
\hline Staff are knowledgeable & & & & & & & & & \\
\hline Staff are professional & & & & & & & & & \\
\hline $\begin{array}{l}\text { Staff do what they say they } \\
\text { will do }\end{array}$ & & & & & & & & & \\
\hline $\begin{array}{l}\text { Staff provide appropriate } \\
\text { answers }\end{array}$ & & & & & & & & & \\
\hline Staff provide quality service & & & & & & & & & \\
\hline $\begin{array}{l}\text { Staff respond within an } \\
\text { acceptable time }\end{array}$ & & & & & & & & & \\
\hline $\begin{array}{l}\text { Staff take an interest in me } \\
\text { and my needs }\end{array}$ & & & & & & & & & \\
\hline
\end{tabular}

2. Research assistance - please indicate your level of satisfaction and importance for each of the following statements

\begin{tabular}{|c|c|c|c|c|c|c|c|c|c|c|}
\hline Research assistance & \multicolumn{5}{|c|}{ How satisfied are you? } & \multicolumn{5}{|c|}{ How important is it to you? } \\
\hline $\begin{array}{l}\text { Assistance from faculty } \\
\text { librarians }\end{array}$ & & & & & & & & & & \\
\hline $\begin{array}{l}\text { Assistance from library staff } \\
\text { using email or SMS }\end{array}$ & & & & & & & & & & \\
\hline Information literacy training & & & & & & & & & & \\
\hline Mendeley workshops & & & & & & & & & & \\
\hline Postgraduate support & & & & & & & & & & \\
\hline
\end{tabular}

3. Any comments about the service you receive from the library? 
4. Please indicate your preference for dealing with library staff

(Select $\mathbf{3}$ options marking them $\mathbf{1}$ for first preference, $\mathbf{2}$ for second preference and $\mathbf{3}$ for third preference) Email

From Blackboard

From faculty LibGuide

From library webpage

Library Facebook page

Personal contact

Telephone

Texting

Other

\section{If you selected "Other", please} explain:

\section{How often do you use the following services?}

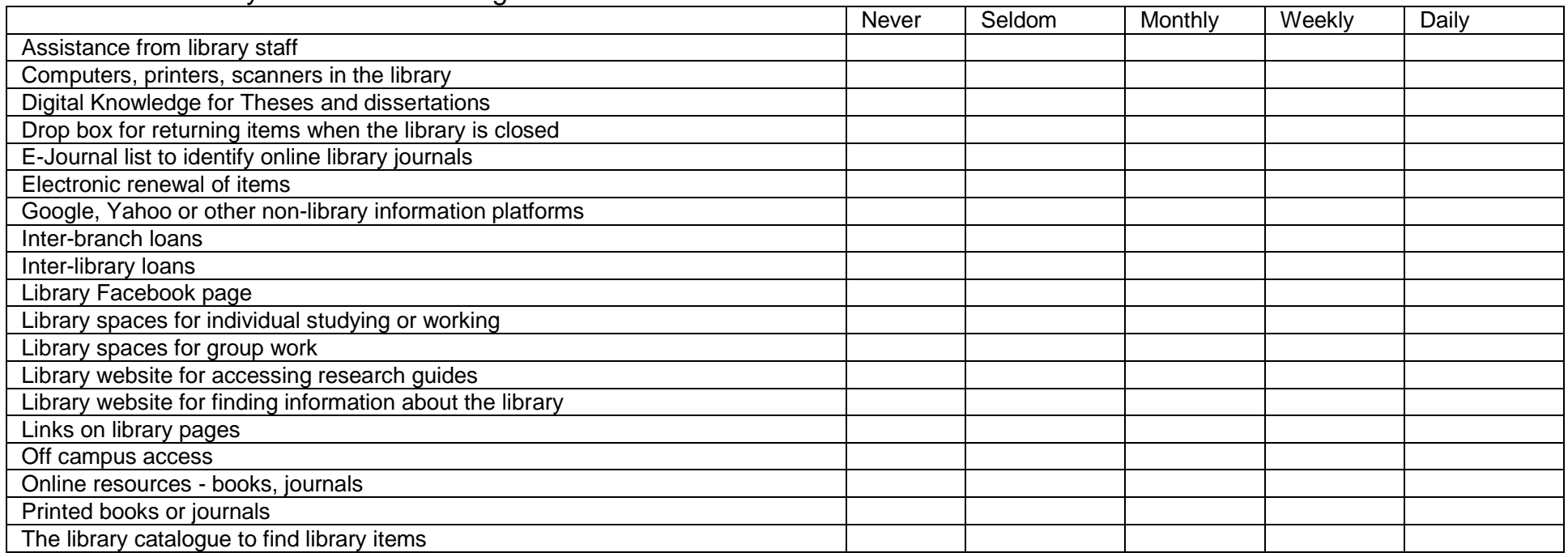

7. Which activities do you do most often in the library? (You may select more than one)

Group study

Individual study

Request assistance from a librarian

Research

Take out library items

Use photocopiers

Use the online collection

Use the print collection

Use computers, printers, scanners

Other

\section{Part 6: Facilities}

1. How satisfied are you with the following library spaces at the libraries you visit?

\begin{tabular}{|c|c|c|c|c|c|}
\hline \multirow{2}{*}{$\begin{array}{l}\text { Library spaces } \\
\text { Please complete for each library you visit: }\end{array}$} & \multicolumn{5}{|c|}{ How satisfied are you? } \\
\hline & Very dissatisfied & dissatisfied & $\begin{array}{l}\text { Somewhat } \\
\text { Satisfied }\end{array}$ & Satisfied & Don't know \\
\hline \multicolumn{6}{|l|}{ Athlone } \\
\hline \multicolumn{6}{|l|}{ Bellville } \\
\hline \multirow{2}{*}{\multicolumn{6}{|c|}{ Cape Town }} \\
\hline & & & & & \\
\hline \multicolumn{6}{|l|}{ Granger Bay } \\
\hline \multicolumn{6}{|l|}{ Groote Schuur } \\
\hline \multicolumn{6}{|l|}{ Mowbray } \\
\hline \multicolumn{6}{|l|}{ MediaCity } \\
\hline \multicolumn{6}{|l|}{ Tygerberg } \\
\hline \multicolumn{6}{|l|}{ Wellington } \\
\hline Worcester & & & & & \\
\hline
\end{tabular}


2. How satisfied are you with the spaces provided in the library you visit most often and how important is it to you?

\begin{tabular}{|c|c|c|c|c|c|c|c|c|c|c|}
\hline Space & \multicolumn{5}{|c|}{ How satisfied are you? } & \multicolumn{5}{|c|}{ How important is it to you? } \\
\hline Convenient service hours & & & & & & & & & & \\
\hline Inspires study and learning & & & & & & & & & & \\
\hline Convenient for group work & & & & & & & & & & \\
\hline $\begin{array}{l}\text { Provides good computer } \\
\text { facilities }\end{array}$ & & & & & & & & & & \\
\hline
\end{tabular}

Comments about services and facilities:

\section{Thank you}

